\title{
German law covering the public participation in planning and building infrastructure projects
}

\author{
Anja Bothe, PhD, Prof. Aux. Dept. of Law, Universidade Autónoma de Lisboa, and \\ Prof. Aux. Dept. of Management Sciences, Universidade Atlântica da Barcarena \\ email: abothe@ual.pt
}

\begin{abstract}
The analysis presented here focuses on the latest German legislation changes introduced in order to make the planning and building of infrastructure projects more harmonious and more effective.

From a due-process perspective, International and European Environmental law played a pioneer role. by leading the German legislators to introduce an earlier public participation in its extremely complex system of spatial and sectorial planning. At first it mainly addressed sustainability. Then, after a few major infrastructure projects were confronted with massive resistance by the population affected, a rethinking about the citizens' involvement at an early stage became necessary, aiming at streamlining and speeding up legally binding decisions on the more controversial infrastructure projects. As a result, the Administrative Procedure Code was expanded to incorporate the "Law for broadening the public participation and for the standardization of the procedures for determining sectorial plans".
\end{abstract}

\begin{abstract}
In order to debate, in an interdisciplinary way, the role that the law is able to play in communication procedures, this article discusses the essential factors impacting the different types of plans and planning. It then questions the strategies leading to acceptance of certain projects and the trade-offs between speed of implementation and the respect for public participation rights.
\end{abstract}

Keywords: public participation, spatial planning, licensing procedure of infrastructure projects, sectorial planning, communication procedures

\section{Introduction}

Large size infrastructure projects, such as airport, rail and road extensions, are particularly likely to encounter frequent citizens' protests. The experience with the enhancements of the Stuttgart train station is an especially relevant example, since it has motivated the economic stakeholders, as well as the German federal and regional legislatures and administrations, to rethink the project. In this case, which has become known as "Stuttgart 21", massive resistance only materialized after the planning approval procedure. As a consequence, the "Law for broadening the public 
participation and for the standardization of the procedures for determining sectorial plans" was introduced in the German legislature in 2012. Among other elements in this law, public participation is now required prior to the formal opening of the procedure for planning and approval of sectorial plans, as described in Article 25, paragraph 3, of the Administrative Procedure Code. In 2013, the Association of German Engineers developed standards governing the communication and public participation in planning and building infrastructure projects. These standards are directed at project sponsors, general and specialist design contractors, project managers, executing companies and their officials. In the same year, regional governments produced binding administrative provisions to intensify public participation in the planning and licensing procedures of large infrastructure projects. These standards and administrative provisions establish several mandatory steps and procedures within the regional planning and approval processes: these mandatory steps include scoping the previous and present participation of the public and their interaction, both at formal and informal levels, conducting an official investigation to show just cause for the project, establishing internet access to the project allowing for on-line search of the detailed plans by the public, a requirement to request and enable public participation periodically as the planning process develops, and a need to reevaluate these new rules as appropriate.

The main objective of these mandatory steps is a more efficient harmonization of the different interests involved in spatial planning. The International, European and German legislation on Environmental Impact Assessment, as well as public participation concerning sustainability, have taught us about the positive impacts of these procedures. This in turn has raised the possibility that we are in fact headed towards a progressively earlier inclusion of the public in the planning process.

In order to establish a more solid foundation for a critical analysis of several of the elements in these rules, this article discusses the essential factors impacting these types of plans, the skills required in their preparation, the strategies leading to acceptance of those plans, and the possible dynamics affecting their implementation.

\section{Types of plans}

Only since 2009 has a Federal Plan of Spatial Development been formally in place. However, that new legal instrument does not cover all aspects of Spatial Development, but rather it only addresses eight areas of policy (Article 2, paragraph 2, of the Spatial Planning Federal Law, the followings are the eight areas of possible Federal Spatial Plans: 1. Sustainability, 2. Urbanization structures, 3. Infra-structure and traffic, 4. Economy, 5. Cultural landscape, 6. Environment and climate protection, 7. Defence and civil protection, 8. European Cooperation). Several major studies of this new instrument have concluded that it is most appropriate for the organization of urbanization structures, infra-structure and traffic communications. 
All-encompassing federal spatial plans, which would cover the coordination of the different affected powers and which would be focussed on implementation, are not foreseen by law. They are only addressed by a set of Federal guidelines that have been produced since 1975. The essential purpose of enacting a Spatial Planning Federal Law is the harmonization of the different interests involved (Article 1, paragraphs 1 and 3, of the Spatial Planning Federal Law).

Before defining the federal and regional skills participating in spatial planning, we need to distinguish between legislation and administration. The administration of spatial planning is a regional skill that resides at the state level, while its legislation perspective is a federal one (Articles 83 and 87 to 90 of the German Constitution). As mentioned, the federal administrators decided not to make use of their powers, but rather to leave that responsibility to the States. The States are thus obliged to produce two levels of spatial plans: one level covering the entire territory of the state and the other level covering only specified portions of the state. Those types of plans need to be distinguished from the planning of certain policy areas. In German law policy planning is separate from spatial planning, because the definition of spatial planning usually relates to several precisely defined policy areas and not just to one. (Bothe, 2014 , p. 306) In order to understand the challenge of coordinating between spatial planning and single-section sectorial planning we need to define the different forms of legal binding.

\section{$3 \quad$ Legal types of binding affecting State plans of spatial development}

Three different types of legal binding (Article 3, paragraph 1, and article 7, of the Spatial Planning Federal Law) are foreseen when formulating State plans for Spatial Development:

- "Goals" must be determined or determinable in spatial terms and content. "Goals" include a complete weighting done by the holder of spatial territory.

- "Principles" of spatial planning are affirmations controlling the development, order and security of space, in the form of demands addressed to the weighting of decisions and the discretionary process that follows. "Principles" can arise as a result of laws or of decisions taken as part of a state's plan of spatial development.

- "Other requirements" of spatial development can be either goals that are in the process of being integrated into a plan, or the result of a formal state's planning process, or the statement of planning intentions made by a State's authority.

"Goals" are the strongest form of legal binding: they must be implemented. The other forms of binding, "principles" and "other requirements", are to be respected 
when possible, but they may not be implemented if other opposing interests are given a higher weight.

The types of legal binding described above are the most important elements affecting the coordination between spatial planning and planning of just one sectorial concern.

\section{$4 \quad$ Possible dynamics affecting the implementation of plans}

In certain limited circumstances public entities which are part of the Federal State can initiate changes to the goals integrated in the plans (Article 5 of the Spatial Planning Federal Law). Other holders that intend to implement the plans have different mechanisms for exerting that dynamic: during the process of elaboration of the plan, they may propose that exceptions be allowed. If that is not successful, "goals" may also be removed after concluding the planning process, if such deviation is justified by regional planning aspects and if the essential of the planning is not affected (Article 6 of the Spatial Planning Federal Law). These exceptions or deviations do not include an outright change of the "goals", but rather a selective modification in order to implement a certain construction or other concretization. This system of exceptions and deviations was introduced in the Spatial Planning Federal Law in 2009, but it had already been widely used by administrations before that date because it was considered legal by jurisprudence (Federal Administrative Court decision of 18th of September of 2003, Proc. 4 CN 20.02 - BVerwGE 119, 54; in the reasoning of the chances in the Federal Spatial Law the legislator affirms the only declarative effect of the new article 6, paragraph 2: Journal of the Federal Parliament $B T$-Drs. - 16/10292, p. 23). Several authors consider that the system of exceptions and deviations lowers the value of regional planning (Kment; Grüner, 2009, pp. 93, 98). Moreover, these authors criticize this practice on the basis that the procedural and content demands for incorporating exceptions and deviations are not defined with sufficient precision (Müller, 2008, pp. 360, 363).

The process of definitely removing a "goal" from a plan is the same as the process for its initial introduction (Article 7, paragraph 7 of the Spatial Planning Federal Law).

\section{$5 \quad$ Regional planning procedure}

One of the most important instruments of planning above local planning is the regional planning procedure (Raumordnungsverfahren - for its definition see article 15 and 16, of the Spatial Planning Federal Law). As mentioned previously, legislation of spatial development issues is a federal skill, but frequently, and also in the case of the regional planning procedure, the Spatial Planning Federal Law just determines the bases of that instrument, and leaves its concretization to the State's legislator. 
Concerning the implementation of major infra-structure projects, it is frequently debatable whether certain decisions are part of the spatial development planning or part of the sectorial planning.

The Spatial Planning Federal Law leaves it to the State's legislator to decide whether public participation is or is not demanded in the regional planning procedure. Six States have established public participation as an obligation on the local administration. The other States leave that decision to the project administration, on a case-by-case basis.

\section{Distinction between spatial and sectorial planning}

The previously mentioned "Law for broadening the public participation and for the standardization of the procedures for determining sectorial plans", which was introduced in the German legislature in 2012, regulates sectorial planning procedures, which are to be distinguished from regional planning procedures. The result of the regional planning procedure is the determination of "other requirements", which are defined in article 3, number 4 of the Spatial Planning Federal Law: they are to be respected when possible, but they may not be implemented if other opposing interests are given a higher weight (see above chapter 3 ).

It is up to the State Authority for Spatial Planning to decide on the necessity of a regional planning procedure. After receiving all the documentation pertaining to that procedure, it has four weeks to decide about the necessity of the regional planning procedure, and six months to conclude on it. The demand for a regional planning procedure does not exist in the three German States that are also cities: Berlin, Bremen and Hamburg.

The objective of the regional planning procedure is a concrete project, and that is why it is difficult to distinguish the regional planning procedure from the determination of a sectorial plan (Bothe, 2014, n. ${ }^{\circ}$ 5, p. 275). The latter is a different instrument, which is not integrated in the spatial planning, but rather in the subsequent sectorial planning. We list below four judged cases in which courts decided that the debatable determinations were part of the regional planning procedure and not part of sectorial planning:

- The location of the new Berlin airport, including closing the old airport and an assessment of the noise levels involved. Only questions about technical feasibility are part of the sectorial planning (Federal Administration Court, 2006, Judgement 125, pp. 116, 167).

- Limitations on night-time airplane traffic at the Frankfurt airport: they were considered a "goal" of spatial planning, meaning that all weighting of interests had been completed, see article 3, number 4 of the Spatial Planning Federal Law (Administration Court of the State of Hesse, Aug 21, 2009). 
- Also the location of part of a highway was considered a legal "goal" of spatial planning (Constitutional Court of Bavaria, July 15, 2002).

- In the State of North Rhine-Westphalia, requirements for greenhouse gas reduction in spatial planning were considered mandatory before closing central power plants based on their carbon footprint (Administration Court of Münster, Sept 3, 2009).

\section{$7 \quad$ Procedure for determining sectorial plans}

Regarding major infra-structure projects, the determination by spatial planning already allows for addressing, at least partially, any concerns regarding soil use. Thus the question arises as to what improvements are still needed to the procedure for determining sectorial plans, in addition to the recent legislation changes:

"Included in the procedure for determining sectorial plans is a decision on the admissibility of the project, whereby the necessary follow-up actions addressing other systems are taken, and all affected public concerns are identified. Once the procedure for determining sectorial plans has been followed, other regulatory decisions such as public approvals, awards, licenses, authorizations, consents and plan approvals are not required. All public relations between the holder of the project and those parties affected by it are defined by the procedure for determining sectorial plans, thus producing the associated legal binding rights." (Article 75, paragraph 1, of the Federal Administrative Procedure Code. "Durch die Planfeststellung wird die Zulässigkeit des Vorhabens einschließlich der notwendigen Folgemaßnahmen an anderen Anlagen im Hinblick auf alle von ihm berührten öffentlichen Belange festgestellt; neben der Planfeststellung sind andere behördliche Entscheidungen, insbesondere öffentlich-rechtliche Genehmigungen, Verleihungen, Erlaubnisse, Bewilligungen, Zustimmungen und Planfeststellungen nicht erforderlich. Durch die Planfeststellung werden alle öffentlich-rechtlichen Beziehungen zwischen dem Träger des Vorhabens und den durch den Plan Betroffenen rechtsgestaltend geregelt.")

Since the dawn of spatial planning one of the major challenges has been how to reach the desired legitimate results in the most effective yet fairest way. Included in those results must be one of the essential characteristics of the procedure for determining sectorial plans: the production of binding rights for everyone involved. The principal motivation for legislators has so far been the speedy achievement of the required results, often lowering the standards of public participation (Journal of the Federal Parliament 17/9666, May 16, 2012: proposal of Law for broadening the public participation and for the standardization of the procedures for determining sectorial plans.). In the beginning of the 1990s, legislation for a speedier production of plans for infra-structure implementation, including all binding rights, was justified by special needs and urgency associated with East Germany. When this special legislation, addressed to the needs of the five States of the former German Democratic Republic, was extended to the rest of the country, the criticisms of the resulting 
reduction in public participation and legal protection became louder and more frequent. Rather extreme examples of citizen protests include those organized to oppose the extensions of the Frankfurt and Berlin airports, and the construction of interim storage facilities for radioactive waste and waste incinerators. These incidents serve as lessons pertaining to several aspects of spatial planning. The federal law, enacted in 2006, for accelerating the planning of infra-structure projects, brought among others the following innovations:

- The Federal Administration Court became the first and last resort for contesting any decisions produced by a procedure for determining sectorial plans

- Public participation became optional,

- Associations formed to deal with spatial impact concerns lost the right to automatically receive information about projects, so that they need to actively maintain themselves up to date like any other citizen,

- Anyone who does not present objections during the public participation period cannot do so later in court, except when that entity has an overriding special subjective civil right.

These innovations were introduced into six special laws in 2006 and were transferred into the general Federal Administration Process Law in 2013.

\section{Prior public participation}

The above-mentioned conflicts over the implementation of major infra-structure projects like airports, highways, etc., have led many to conclude that it is imperative to introduce changes adding citizens' rights instead of lowering their standard. The previously referred Law for broadening the public participation and for the standardization of the procedures for determining sectorial plans, for instance, has introduced public participation prior to the formal opening of the procedure for planning and approval of sectorial plans. Towards that objective, this law states that "The authority must do the utmost to ensure that the holder, who is planning a project that might have impacts essential to the interests of a large number of citizens, must inform the affected public about the goals of the project, the way the project is to be realized, and the probable effects of that project (prior public participation)." (Article 25, paragraph 3, of the Administrative Procedure Act: "Die Behörde wirkt darauf hin, dass der Träger bei der Planung von Vorhaben, die nicht nur unwesentliche Auswirkungen auf die Belange einer größeren Zahl von Dritten haben können, die betroffene Öffentlichkeit frühzeitig über die Ziele des Vorhabens, die Mittel, es zu verwirklichen, und die voraussichtlichen Auswirkungen des Vorhabens unterrichtet."). This new legal instrument became generally effective in June 2013, although for some federal sectorial acts it only became effective in June 2014. In 
March 2015 the Federal Government was the subject of an inquiry in the Federal Parliament about its accumulated experience with this mode of prior public participation. The Federal Government informed the Parliament of 36 cases of road construction projects including prior public participation, as well as 25 railway projects and 19 water infra-structure projects. The inclusion of prior public participation in several of these projects actually happened independently of the new legislation, because when the initiatives started the States had not yet incorporated the Federal Administrative Procedure Code into their State Administrative Procedure Codes. While the Government advocated that "prior and continuous public participation is a central part of the successful realisation of traffic infra-structure projects", (Journal of the Federal Parliament 18/4159, March 2, 2015) other parties supported an even earlier public participation. According to these parties, prior public participation should not only be part of the sectorial planning procedure, but should also be included in the Regional planning procedure, because spatial planning usually takes place before a concrete plan has been produced. Continuing along the same logic - that the earlier the public is involved the more effective is the harmonization of the process - and analysing the evolution of the European and national legislations regarding the evaluation of environmental impacts of territorial projects, ( Directive 2003/35/EC of the European Parliament and of the Council of 26 May 2003 providing for public participation in respect of the drawing up of certain plans and programs relating to the environment and amending with regard to public participation and access to justice Council Directives 85/337/EEC and 96/61/EC - Statement by the Commission.) it may be concluded that public participation has happened progressively earlier in the project timeline after each legislation change. However, it must be recognized that many essential decisions are made long before both of the referred procedures, the regional planning procedure and the procedure for determining sectorial plans, take place. The decision regarding the if of the project, in particular, is usually made during the federal planning of traffic routes (Bundesverkehrswegeplanung). This basic decision about the need for the project establishes early legal binding affecting all the subsequent planning procedures. This binding includes a rough definition of the communication process and the classification of the type of route. All these essential steps are thus legally considered to be an internal instrument of the Federal Government. They are usually integrated in the Federal laws ruling the extension of highways or railways. Although these decisions are binding and address many essential elements, they only impose an analysis of alternatives and public participation, the latter only since 2006 when the Public Participation law became effective. However, the objective of the public participation is limited to environmental concerns.

\section{International sustainability concerns as a valuable forerunner in public participation tools}

The integration of ecological concerns in the planning process has been a reality in the European Union since 1985, as a consequence of the Directive on Environmental 
Impact Assessment (Directive 85/337/EEC on the assessment of the effects of certain public and private projects on the environment, EIA). This is the first European Union instrument concerning all environmental sectors simultaneously, and it reflects the regulatory philosophy of Niklas Luhmann, namely the "legitimation by due process". It is all about process, as expressed by the text of the law: "The environmental impact assessment shall identify, describe and assess in an appropriate manner, in the light of each individual case...the direct and indirect effects of a project on the following factors:- human beings, fauna and flora;- soil, water, air, climate and the landscape; - material assets and the cultural heritage;..." (Article 3 Council Directive 97/11/EC, March 3, 1997 amending Directive 85/337/EEC on the assessment of the effects of certain public and private projects on the environment).

Until 2001, the public participation was supposed to be introduced before the realization of certain projects, but not before the beginning of the planning stages, which we nowadays consider to be too late: "1. When a decision to grant or refuse development consent has been taken, the competent authority or authorities shall inform the public thereof in accordance with the appropriate procedures and shall make available to the public the following information:

- the content of the decision and any conditions attached thereto,

- the main reasons and considerations on which the decision is based,

- a description, where necessary, of the main measures required to avoid,

reduce and, if possible, offset the major adverse effects." (Article 9 Council

Directive 97/11/EC, March 3, 1997)

In 2001 was approved its "sister directive" (Directive 2001/42/EC of the European Parliament and of the Council of 27 June 2001 on the assessment of the effects of certain plans and programmes on the environment.) "This Directive requires certain plans and programmes, which are likely to have significant effects on the environment, to be subject to an environmental assessment. This assessment specifically enables environmental considerations to be integrated in the preparation and adoption of these plans and programmes. It (...) includes the introduction of an environmental report (...), as well as carrying out consultations (with the public, the authorities with environmental responsibilities...)." (The official summary of the directive can be found in http://eur-lex.europa.eu/legal-

content/EN/TXT/HTML/?uri=URISERV:128036\&from=DE). The principal lesson learned from the experience with the first directive is that all evaluation including public participation needs to occur much earlier: not only when the project is to be implemented, but in the early stages of the elaboration of the plan.

In the meanwhile, the European Union was already obliged to realise the mentioned revisions because it signed the Aarhus Convention, the United Nations Economic Commission for Europe (UNECE) Convention on Access to Information, Public Participation in Decision-Making and Access to Justice in Environmental Matters (adopted on 25 June 1998 in the Danish city of Aarhus at the Fourth Ministerial Conference as part of the "Environment for Europe" process. It entered into force on 30 October 2001). The Convention provides for the following three rights: 1."access 
to environmental information", which means that it is to be made possible for everyone to receive environmental information that is held by public authorities in order to participate in environmental decision-making. 2. "public participation in environmental decision-making": "Arrangements are to be made by the public authorities to enable the public affected and environmental non-governmental organisations to comment on, for example, proposals for projects affecting the environment, or plans and programmes relating to the environment. These comments are to be taken into due account in decision-making, and information is to be provided on the final decisions and the reasons for it." (European Commission, http://ec.europa.eu/environment/aarhus/). 3. "Access to justice", the right to review procedures to challenge public decisions that have been made without respecting the two aforementioned rights or the environmental law in general.

(http://ec.europa.eu/environment/aarhus/)

Therefore we can conclude that the European Union Environmental Law has been a forerunner or pioneer in public participation: It first obliged the national legislators to introduce public participation at progressively earlier stages of each project. One of the latest developments came from the Grid Expansion Acceleration Act transmission network (NABEG, Article 20 Application conference) establishing the need for an early public meeting for defining the scope of the project. The mandated application conference is unlike a conventional scoping appointment, since it is not limited to the scope and methods of environmental impact assessment, but extends instead to all of the planning approval process, considering a large range of issues related to the intended project (paragraph 1 sentence 2). And while the scoping concerning the environmental impact assessment is to be realized with participation of the public authorities, the referred Grid Expansion Acceleration Act transmission network (NABEG) includes the public in the full scoping process. "Thus, the application conference is a crucial building block to further develop the existing participation rights in major projects through confidence and acceptance-enhancing measures. Conflicting public and private interests come to the fore at an early stage of the procedure and thus ensure full consideration of the needs of the general public. The application conference thus contributes to process transparency, acceptance and peace. It also serves to accelerate the planning approval procedure." (Federal Parliament Publication, 2011, p. 28) The reflections described above are currently limited to the planning process, according to the Grid Expansion Acceleration Act transmission network. Will they in the future expand to general sustainability concerns, or even to all types of planning and all types of interests presented by the public?

\section{Assessing the new legislation}

Summarizing the elements introduced by the new legislation, incorporated in the Federal Administrative Procedure Code, that are aimed at speeding up the process of producing binding rights, we must consider the following aspects: 
10.1. The authorities in charge of the procedure for determining sectorial plans have been given more power of discretion to decide what communities must be involved in the public participation process. (Article 73, paragraph 2, Federal Administrative Procedure Code.)

10.2. The participation of special-interest associations occurs right at the beginning of the decision process, together with the public entities involved. (Article 73, paragraph 4, Federal Administrative Procedure Code.) If these associations do not present a particular opinion, they lose their right to do so afterwards. This is advantageous for the authority in charge of the process since they do not need to worry about new opinions being introduced at a later stage. For the associations, however, it means that they lose their right of participation throughout the process unless they manage to be well prepared and organized during the very early stages of the public participation process.

10.3. The legislation introduces deadlines aimed at forcing the authority in charge of the procedure to establish a clear schedule and puts some pressure on them to respect it. (Article 73, paragraph 6, in fine, Federal Administrative Procedure Code) Nevertheless, these deadlines are weakened by the fact that there are no consequences if they are not met. Moreover, subsequent legislation changes lowered the bar further by limiting even more the types of procedure failures that carry legal consequences. (Article 75, paragraph 1a, and articles 45 and 46, Federal Administrative Procedure Code)

10.4. To recap, how would we rate the new process of public participation prior to the formal opening of the procedure for planning and approval of sectorial plans? As mentioned above, (see chapter 8 ) one of the most fundamental criticisms of this new instrument is the exclusion of public participation in the initial decision about whether or not to pursue the project, except for consultation of the public regarding ecological concerns. The German legislators were forced to introduce early public participation by the European Directive 35/EC of 2003. However, the new public participation prior to the formal opening of the procedure for planning and approval of sectorial plans is optional in all of its aspects because the legal expression is not sufficiently precise and thus admits several interpretations. It stipulates that the authority must do the utmost to ensure that the holder, who is planning a project that might have impacts essential to the interests of a large number of citizens, must inform the affected public about the goals of the project, the means to achieve those goals, and the expected impacts of the project (prior public participation, Article 25, paragraph 3, Federal Administrative Procedure Code). But it does not define precisely what doing the utmost means. Therefore, the new legal instrument is for all purposes optional for the authority, as well as for the investor, who can choose the content of the information released to the public and the way to present it.

\section{Conclusion}

In conclusion, does the new legislation achieve its aim of reaching a result with binding rights in a faster and more harmonious way? 
Empirical studies show that non-governmental organizations, NGOs, face very few legal processes, and when they do so the processes are concluded quite fast and in $40 \%$ of them the NGO wins the process. (The same percentage of individual legal processes is about 10 to $12 \%$, see Independent Institute for environmental questions, Lawsuits of associations in the law of nature and environmental protection, 2013, p. 3) These organizations consider that their rights are very dependent on the information they receive and also on the possibility or not of participating at a later stage, even if they failed to present opinions at an earlier stage of the process. (Schmidt, et. al., 2011, p. 6; 69th Meeting of German Lawyers, 2012, p. 51) Federal departments have analysed the time management of the implementation of major infra-structure projects, and they concluded that many months usually elapse between the conclusion of the administrative process and the beginning of the work. (Federal Government; German Parliament, Circular 18/4159, 2015). These conclusions lead us to believe that the main reasons behind delays in starting the work are not legal ones.

A clear and efficient harmonization of the interests involved promotes a faster start of the work. That is why several entities published recommendations for the procedure of public participation (Association of German Engineers: Standard AGE 7000 about prior public participation for industry and infra-structure projects, 2015; European Commission: Guidance on Integrating Climate Change and Biodiversity into Strategic Environmental Assessment, 2013; University of applied sciences: Final Report on the analyses: Evaluation of the Federal environmental impact assessment act, 2008; Federal Authority for Environment: Guides for authorities and legal recognition, 2015; Federal Ministry for traffic and digital infrastructure, Manual for a good public participation, 2012). The following are some of their reflections, conclusions and experiences:

\subsection{More or less legal demands?}

There are pros and cons concerning the extent of mandatory legal demands: on the one hand they aim at facilitating communication, which has raised concerns with some authors about this not being a suitable object of legal rules (69th Meeting of German Lawyers, 2012, p. 44). Each case is very specific, (69th Meeting of German Lawyers, 2012, p. 49), and often the parties being legally mandated to this enhanced communication may tend to see the other parties as an opposition. On the other hand, legal rules that are only voluntary end up bypassing discussion of uncomfortable matters, which will lead to increased conflicts during the later stages of the project (69th Meeting of German Lawyers, 2012, p. 41).

\subsection{Common plan about the exact procedure of planning and the coordinating party}

From the very beginning of the process, technical aspects, communication, legal aspects and financing considerations must all be taken into account. (Association of German Engineers, 2015) A neutral authority, working together with all parties involved, should establish a plan about the proper procedure, especially about the liability of the decisions taken in each stage of planning. (69th Meeting of German 
Lawyers, 2012, p. 42). However, while some consider essential that this coordination be carried out by a neutral authority (69th Meeting of German Lawyers, 2012, p. 42), others point out the disadvantages that arise from the fact that the procedure coordinating authority and the decision making authority are not the same:

- the waste of material resources,

- the increased requirements of communication

- $\quad$ the blurring of responsibilities (69th Meeting of German Lawyers, 2012, p. 51)

- the less concentrated information level (69th Meeting of German Lawyers, 2012, pp. 12, 45).

For the holder of the project an integrated project management is usually recommended, as opposed to a complete outsourcing of the communication process.

In order to form engineers possessing the necessary communication sensibility, universities should integrate the necessary subjects into their education program. Notwithstanding, for maximum effectiveness communication teams should be interdisciplinary.

\subsection{Positive experiences with accompaniment in difficult periods}

There have been a few positive experiences with sensitive practical problems being introduced and discussed progressively in stages, overseen by a neutral authority, like in the following examples related by the Association of German Engineers ${ }^{\mathrm{i}}$ :

- During the reconstruction of the Wiener Central Station an ombudsman was always present to oversee the needs and concerns of frustrated neighbours.

- The two year mediation process for the extension of the Frankfurt airport interlinked the extension work with an anti-noise treaty, the prohibition of night flights and the establishment of a regional dialog forum.

\subsection{Assessing the potential for influencing decisions and its limitations}

It is difficult to select the right moment to introduce public participation in the planning process: when it occurs too early the issues may be too abstract for the public, which does not yet feel directly affected. Nevertheless, the initial decision about the need for the project is obviously central in the planning procedure, and public participation in that decision is highly desirable. (Federal Ministry for traffic and digital infrastructure, 2012, p. 27) When public participation is introduced too late, there is usually no openness on the part of the authorities and the project holder to accept any changes to the decisions that have already been made.

When there are no viable alternatives to the project, it is not correct nor effective to pretend that there might be one. In these situations, the environmental associations in 
particular are seen by the authorities as being the enemy standing in the way of an effective implementation of a necessary project (Fehling, Michael, 2012). In these cases it is often better to assume that public participation is to be meant as participation in the procedure, but not as participation in the decision which is seen as inevitable (69th Meeting of German Lawyers, 2012, p. 44).

Naturally, questions about the kind of democracy we want and what are to be its basic values have been the motivation behind several deep conflicts. They need to be confronted, but the planning procedure itself has different objectives (69th Meeting of German Lawyers, 2012, p. 46).

\subsection{Deterioration of material conditions and motivation}

Environmental associations tend to have increasingly less material conditions to realise their objectives: they have progressively fewer personnel and weaker financial capacities. Consequently, they often do not have much faith in the effectiveness of their work. In a recent opinion survey, $79 \%$ of the people participating in these associations stated that they consider that their work has no influence, or an extremely small influence, on the decisions (University of applied sciences, 2008). These facts lead to a lack of balance between the investor and the public. In order to even out the playing field, it would be necessary to financially support at least a portion of the costs of the citizens' associations (Independent Institute for Environmental concerns, 2013; 69th Meeting of German Lawyers, 2012, p. 52).

All in all we conclude that the controlling force of the law is weaker than the combined power of all other influences.

\section{References}

Administration Court of Münster, (2009), OVG NRW, Sep 3, 2009, in ZNER, Review for the New Energy Law, 2009, vol. 3, pp. 284, 289.

Administration Court of the State of Hesse, (2009), HessVGH, Aug 21, 2009, in LKRZ, Review for the Law of the States and the municipalities of Hesse, Rhineland Pfalz, e Saarland, vol. 2, 2010, pp. 66, 69 and following.

Association of German Engineers, (2015), Verein Deutscher Ingenieure, Standard AGE 7000 about prior public participation for industry and infra-structure projects, http://www.vdi.de/7000/ Accessed Sep 25, 2015.

Association of German Engineers, AGE news, Vdi nachrichten http://www.vdinachrichten.com/Technik-Gesellschaft/Wir-voellig-neue-Dialogkultur/ Accessed Sep 25, 2015. 
Bothe, Anja, (2014), Classification and qualification of the ground on the right of the German urbanism, A classificação e a qualificação do solo no direito do urbanismo alemão, in JURISMAT, Legal Magazine of the Institute Manuel Teixeira Gomes, n. ${ }^{\circ}$ 5, 2014, pp. 271 - 285

Bothe, Anja, (2014), Law of Urban Planning, Spatial Planning and the Land in Portugal and Germany, Direito do Urbanismo, do Ordenamento do Território e dos Solos em Portugal e na Alemanha, in JURISMAT, Legal Magazine of the Institute Manuel Teixeira Gomes, n. ${ }^{\circ}$ 4, 2014, pp. $289-319$.

Constitutional Court of Bavaria, (2002), BayVerfGH, July 15, 2002, in DÖV, Review of Public Administration and Administration Science, 2003, pp. 78, 80.

European Commission, (2013), Guidance on Integrating Climate Change and Biodiversity into Strategic Environmental Assessment.

Federal Authority for Environment, (2015), Bundesumweltamt, Innovative public dialogue process with environmental assessment using the example of certain types of projects / project properties - Guides for authorities and legal recognition, Neuartiger Öffentlichkeitsdialog in Verfahren mit Umweltprüfung am Beispiel bestimmter Vorhabentypen/Vorhabeneigenschaften - Leitfäden für Behörden und rechtliche Verankerung.

Federal Administration Court, Judgement, (2006), 125, pp. 116, 167, note 155. http://www.bverwg.de/entscheidungen/entscheidung.php?ent=160306U4A1075.04.0 Accessed March 27, 2014.

Federal Government, (2015), Experience Report, Erfahrungsbericht, - German Parliament, Circular 18/4159, March 2, 2015, http://dip21.bundestag.de/dip21/btd/18/041/1804159.pdf / Accessed Oct 10, 2015.

Federal Ministry for Traffic and digital Infrastructure, (2012), Manual for a good public participation, Handbuch für eine gute Bürgerbeteiligung.

Federal Parliament, (2011), Fundamentation of the law, Federal Parliament Publication, BTDrucks. 17/6073, 6.6.2011, http://dip21.bundestag.de/dip21/btd/17/060/1706073.pdf, Accessed Sep 20, 2015

Fehling, Michael, (2012), Reform of public participation for plan approval of infrastructure projects, Reform der Bürgerbeteiligung für die Planfeststellung von Infrastrukturvorhaben, in Transport Scientific Seminar, Verkehrswissenschaftliches Seminar, Freiburg, Sep 20, 2012.

Independent Institute for Environmental concerns, (2013) Unabhängigies Institut für Umweltfragen, Public participation in environmental protection in Germany - Status Quo and new ways, Öffentlichkeitsbeteiligung im Umweltschutz in Deutschland - Status Quo und neue Wege.

Kment, Martin/ Grüner, Johannes, (2009), Exceptions of the goals of spatial planning - about the new concept of the Spatial Planning Federal Law, Ausnahmen von Zielen der Raumordnung - zur Neufassung des Raumordnungsgesetzes, in UPR (Magazine for the Environmental and Planning Law), pp. 93-111

Müller, Christian, (2008), The proposal of the Spatial Planning Federal Law, Der Referentenentwurf des Raumordnungsgesetzes 2008, in RUR (Magazine for Spatial Science and Spatial Order), pp. 360-374. 
Schmidt, Alexander, et. al., (2011), The development of collective action in nature and environmental protection law 2007 to 2010 - an empirical study commissioned by the Federal Agency for Nature Conservation, Die Entwicklung der Verbandsklage im Natur- und Umweltschutzrecht von 2007 bis 2010 - eine empirische Untersuchung im Auftrag des Bundesamtes für Naturschutz https://www.bfn.de/fileadmin/MDB/documents/themen/recht/BfN-Verbandsklagen-Studie2011.pdf / (Accessed Sep 25, 2015).

$69^{\text {th }}$ Meeting of German Lawyers - 69. Deutscher Juristentag, (2012), Theses of the experts and speakers, Thesen der Gutachter und Referenten, Ziekow, Jan, pp. 41 - 43; Dolde, Klaus-Peter, pp.43 - 45; Gabriel, Oscar W., pp. 46 - 49; Wegener, Bernhard W., pp. 49 - 52

Spatial Planning Federal Law. http://www.mlit.go.jp/kokudokeikaku/international/spw/general/germany/index e.html./ Accessed Sep 25, 2015.

University of applied sciences, Hochschule Darmstadt, et. al. (2008), Final Report on the analyses: Evaluation of the Federal environmental impact assessment act, Abschlussbericht zum Vorhaben: Evaluation des UVPG des Bundes. 